\title{
“As White as Most White Women": Racial Passing in Advertisements for Runaway Slaves and the Origins of a Multivalent Term
}

\author{
Martha J. Cutter
}

In 1731 a man named Gideon Gibson, along with several of his relatives, emigrated from Virginia to South Carolina. At first it was reported with consternation that Gibson was a free black man married to a white wife. ${ }^{1}$ However, when the South Carolina House of Assembly took up an investigation of Gibson, then governor Robert Johnson concluded that the Gibson family were "not Negroes nor Slave but Free people." 2 The Gibsons were allowed to remain in the colony, and they prospered, eventually purchasing 450 acres of prime South Carolina land; Gibson owned black slaves, and his sister married a wealthy planter. Gideon Gibson's son married a white woman and himself became the owner of at least seven slaves. It would be forty-five more years before the colonies declared independence from Britain, but it seems the Gibsons had already declared themselves free from the social, legal, or ideological codes that would construct them as black, Negro, or mulatto. Another investigation in 1768 revealed that Gideon Gibson, Jr., "escaped the penalties of the negro law by producing upon comparison more red and white in his face than could be discovered in the faces of half the descendants of ... [the House of Assembly]."3 Gideon Gibson, Jr., was judged to have been passing for white; he was in actuality a very light-skinned black man with black ancestors. ${ }^{4}$ Yet he was also a slave owner and a prosperous member of South Carolinian society. 
On May 15, 1845, an enslaved black woman named Fanny ran away from her Alabama owner. Since Fanny could read and write, her owner speculates in an advertisement posted in the Alabama Beacon (June 14, 1845) that she might forge a pass for herself. But Fanny's master also comments that "she is as white as most white women, with straight light hair, and blue eyes, and can pass herself for a white woman." Fanny can pass for white, but indeed one wonders what her owner means when he says that she is "as white as most white women." Are many "white women" not quite "pure" white? And yet they are not subject to perpetual enslavement, as Fanny is. Fanny is also described as "very pious" and "very intelligent." This valuable piece of "property," it is implied, in other ways is no different from a white woman. She is religious, rational, and light-skinned. In what ways is she not, the advertisement seems to wonder, a "white woman"? The advertisement appears to grant Fanny humanity as more than property, even as it seeks to re-enslave her. Her owner seems to know that nothing but "a fiction of law and custom"- to borrow Mark Twain's words in Pudd'nhead Wilson (1894) - keeps her enslaved. ${ }^{6}$

Although some scholars argue that racial passing began in earnest in the mid- to late nineteenth century, reached its pinnacle in the early twentieth century, and then abated or became "passé" by the 1930s, ${ }^{7}$ these two incidents and many others discussed in this essay indicate that, as both a word and a behavior, passing has a longer and more extensive early history and genealogy. Moreover, its meaning is unstable and changes based on historical context. When Gideon Gibson passed for white in 1731 , he did so to migrate into a category of identity that empowered him in a period in which such racial migration was somewhat acceptable because ideologies of black racial inferiority had not yet solidified. That he owned slaves himself indicates that he did not see his passing as a challenge to the codes of law that allowed the perpetual possession of black human property; for Gibson slaveholding might have been a sign of his wealth, status, and power, rather than a racially inflected behavior. Fanny's owner, on the other hand, manifests a more convoluted attitude toward passing and race, because by 1845 the ideology of African American physical and mental inferiority was entrenched and often used to rationalize the fact that blacks were the only group of individuals who could legally be held in perpetual enslavement in the United States. Matthew Frye Jacobson argues that in the United States, "whiteness" denoted "not only color but degree of freedom (as against 'coolies'), level of civilization (as against 'cannibals'), and devotion to Christianity (as against 'heathens' and 'pagans')." Yet Fanny is Christian, refined, and can pass for a white woman so well that no one can tell the difference; so what, exactly, is the difference between her and a "real" white woman? Advertisements for runaway slaves are clearly part of hegemonic ideology and discourse (systems of language and belief that attempt to conform to the dominant society), yet these advertisements sometimes function in a counter-hegemonic way. As legal scholar Ian Haney López has noted, race is "neither an essence nor an illusion, but rather an ongoing, contradictory, self-reinforcing process subject to the macro 
forces of social and political struggle and the micro effects of daily decisions." These documents illustrate how this process of racial construction functions, but they also at times query the social, legal, and ideological classifications that demarcate race - that attempt to separate blackness from whiteness as a supposedly inferior, unchanging, hierarchical category of racial identity.

This article brings a strong interpretive lens to the early history of racial passing by examining advertisements published in newspapers from 1747 to 1860 for runaway enslaved blacks who passed racially. ${ }^{10}$ To assess this topic, I created an archive of more than a hundred advertisements for runaway slaves that use the actual term "to pass" or "pass for" in a racialized sense. ${ }^{11}$ I have located advertisements stating that enslaved individuals would pass for white men or women, would use their light skin to pass for free, would pass for Indian or another nationality (such as French), and would pass for married white people or families (necessitated by the fact that legal marriage was a privilege reserved in this time period for free people, not slaves, and black enslaved kinship was frequently denied). My goal was to illuminate some of the connotations of the term over a broad period to assess any historical or geographical patterns that might emerge; however, I did not want to overlook the racial multivalences of passing - the way, as historian David Waldstreicher puts it, many of these advertisements "create difficulties for any attempt to isolate and describe a unitary and coherent black (or white, or Native American) historical experience."12

I did not find any unambiguous historical patterns, other than the fact that after the American Revolution (when ideologies of black racial inferiority solidified and the indentureship of whites gradually ceased), passing for white and for free are more frequently conjoined. In addition, in the thirty years leading up to the start of the Civil War, the attempt to fix black racial difference becomes more insistent, but even here the data are not absolute. I have therefore organized this essay topically, rather than historically or geographically, since the archive tells us less about a specific history of racism in the colonies and the United States and more about the way racial ideologies are made and remade. As historian Barbara Jean Fields points out, race is an ideology — a "descriptive vocabulary of day-to-day existence, through which people make rough sense of the social reality that they live and create from day to day" and the ideology of race needs to be "constantly created and verified in social life."13 These advertisements speak to the ways ideologies of race are relentlessly constructed, deconstructed, and reconstructed over time.

Scholarship on advertisements for runaway slaves has examined this data in terms of the information contained about literacy, legal codes, print history, enslaved agency, and perception of racial or ethnic identity. ${ }^{14}$ Yet to date no study has examined the actual usage of the term "pass" in these advertisements, especially as regards racial passing itself-its meaning and its potential to undermine fixed ideologies of racial difference. Werner Sollors defines passing as "the crossing of any line that divides social groups." 15 To this useful classification I would add that passing is the crossing of any line that divides social 
groups that are conceptualized as distinct from each other and as wielding differential social power. Sollors also argues that the term originates in advertisements for runaway slaves, but he dates these advertisements to the 1780s and connects the term (first) with passing for free, not white. However, as I show, advertisements for runaway black slaves utilize the term routinely in a variety of racialized contexts from 1747 onwards, and it is initially connected with passing for white, rather than for free.

In the documents examined the term does not connote a single behavior or even a single attitude toward racial ideology. Some general propensities can be seen, however. The archive suggests that while laws from state to state and in different time periods varied, the idea of an enslaved individual from a black family heritage deliberately passing for white was frequently configured as duplicitous and even incendiary. In the first half of the nineteenth century, racial ideology in the United States became constellated around several key ideas: that whites were an inherently superior, civilized, intelligent, and free race, while blacks were an inherently inferior, savage, unintelligent, and unfree one; that one was black if one had a single black ancestor; and, most importantly, that racial characteristics were fixed and racial status unchanging. ${ }^{16}$ Passing successfully for white might constitute a challenge to this ideology. Although written by slave masters - many of whom adhered to this construct of race to some degree - the advertisements themselves point to the instability of racial codes defining whiteness and blackness. ${ }^{17}$ "How can a human being be both a person and a thing?" asks historian Agnes Smedley. She answers that racial ideology evolved as one way of dealing with this paradox, as Africans and their descendants were eventually defined as "less than fully human, or a different and inferior form of human being from whites." 18 This opposition between being both a person and a thing is fully on display in these advertisements.

Ultimately, these advertisements contain a double-edged content, as they simultaneously support and transgress the racial ideology they are designed to protect. First, while print culture from this period attempted to control these bodies by making them visible and readable as "black" escaped slaves, there is evident resistance to this visuality within the enslaved themselves, who clearly do not believe in the ideology of racial inferiority or perpetual enslavement. Many advertisements for passers depict individuals who are intelligent, civilized, and "white" or "almost white"; they also portray men and women who can move from one racial category to another easily and fluidly, through use of clothing, hair, speech, or other racialized markers. Second, then, these transformative, intelligent, near-white individuals at times put the master's ideology of fixed racial difference and the "thingness" of the enslaved into some degree of turmoil. This archive of documents therefore at times tells a story in which the passing individual makes his or her body a site for category crisis, resistance to hegemonic and binary norms of blackness and whiteness, and (occasionally) subversion of the systems of meaning that govern racial ideology itself. ${ }^{19}$ These early documents therefore foreshadow many contemporary perplexities about 
the implication of racial passing and the definition of racial identity - questions that have not vanished in our own era.

\section{Historical Overview: From Racial Migration to Racial Fixity}

Fields argues that the laws that marked African or African-descended slaves as subject to the condition of perpetual slavery did not come into being until 1661 and that Euro-Americans "resolved the contradictions between slavery and liberty by defining Afro-Americans as a race" sometime between the time of the American Revolution (1776) and the ratification of the Constitution (1788) ${ }^{20}$ Ira Berlin is more sensitive to the ways the idea of perpetual enslavement was negotiated in different parts of the United States because of disparate labor systems but still sees a new order based in permanent African slavery developing in the last decades of the seventeenth century. ${ }^{21}$ David Brion Davis has also examined the profound ways that, during the era of the American Revolution, individuals who opposed slavery were complicit with those who favored it and settled on race as an explanation for the existence of slavery; in so doing both groups coalesced racist ideologies of blackness. ${ }^{22}$ Certainly, slavery in North America was not the result of a single set of laws but rather of numerous acts, decisions, and habits that became codified over time into legal frameworks regionally in colonial societies and states. ${ }^{23}$ Ultimately, though, in the late eighteenth century these codifications produced a system of bondage that rested on perpetual enslavement being reserved solely for black Africans and their descendants.

Prior to the American Revolution, white orphans, convicts, and "free-willers" (individuals who booked passage to the colonies in exchange for some period of indentured servitude) were brought into the colonies and kept in harsh servitude for periods from four to fourteen years (and sometimes for their entire life), and many died from harsh treatment, starvation, or disease. Advertisements for runaway white indentured servants are therefore also frequent in early periods of the databases I have searched. A few decades after the Colonies established their independence from Britain, however, these practices mostly appear to have ended. In 1791 the importation of white convicts as servants was banned by law across the United States, and in 1820 the white indentured servant trade lost its profitability because of changes in ship design that made the journey to the United States cheaper and therefore within the reach of the poor. ${ }^{24}$ This did not mean, of course, that white indentured servitude disappeared, but it had certainly died down by the early nineteenth century. Blacks were thus left as the only exploitable and profitable racial group permanently enslaved as laborers in the United States.

Moreover, after the importation of slaves from Africa was banned in 1807 , a class within the enslaved population rapidly emerged who looked white but were in fact legally black, being born of very light-skinned slave mothers, often 
fathered by slave owners, an event curated in numerous fictional and nonfictional texts. In the decades preceding the Civil War, racist rationales for keeping a "black" slave (no matter how white-looking) in perpetual bondage therefore were fortified not only legally but also ideologically. The notion of perpetual enslavement of black Americans was subtended by ideologies of physical inferiority and (eventually) the argument that "one drop" of "black blood" made an individual black. Before the American Revolution, a certain amount of racial migration seems to have occurred and been tolerated, at least by individuals who were not enslaved, as legal historian Daniel Sharfstein has argued. Sharfstein does, however, see a transition of the "one-drop rule" from an "ideological current" to a "legal bright line and presumed social reality" in the thirty years preceding the Civil War. ${ }^{25}$

The solidification of the one-drop rule undoubtedly is difficult to pinpoint; some scholars have attempted to trace the rule's origin to the emergence of the cotton economy in the 1830 s, to sectional crisis in the 1850 s, to Reconstruction, or to the 1910 s and 1920 s, when most Southern state legislatures formally adopted one-drop racial classifications. The one-drop rule is also difficult to define because it has been assessed in a variety of ways. It was and is often described in terms of the concept that a single black ancestor makes a person black. ${ }^{26}$ Because genealogical records at times were scarce or ambiguous, however, appearance was often relied upon and came to be a proxy for genealogy; if the person looked entirely white, and had been treated and viewed as white, he or she was, in court cases such as Guy v. Daniel (1855) and Morrison v. White (1858), viewed to be white. ${ }^{27}$ Nonetheless, as the possibility of freedom approached for black Americans as a group, there was an anxious attempt to demarcate and stabilize blackness, and a variety of state court cases and statutes attempted to legislate white purity through the language of the one-drop rule. ${ }^{28}$

An early articulation of the one-drop rule in American law occurred in the 1843 Ohio State Supreme Court case of Lane v. Baker. The attorney for the defendant (William Ellsberry) attempted to argue that the "term white, as applied to persons, has ... been ... applied as expressive of the pure white race," but Judge C. J. Lane ultimately allowed a boy who was "of negro, Indian and white blood" to attend school with whites, without stipulating whether said individual was white, black, or Native American. ${ }^{29}$ The rise of the one-drop rule is more strongly evident in Virginia in 1853 when the state legislature debated a proposal to "declare all persons to be negroes who may be known or proven to have negro blood in them." ${ }^{30}$ In 1857 the Louisiana Senate similarly entertained a bill for the "prevention of marriages where one of the parties has a taint of African blood." 31 Also in 1857 the Arkansas Supreme Court construed the term "mulatto" to mean "persons belonging to the negro race, who are of an intermixture of white and negro blood, without regard to grades." ${ }^{32}$ In Indiana in 1863 a measure made it to a floor vote in the state senate, failing by a two vote margin, which would have defined black racial status as "possessing any negro blood." 33 As Sharfstein comments, then, "before the one-drop rule's widespread 
codification in the 1910s and 1920s, the color line was formally demarcated through a patchwork of statutes and common law rules. ... These rules were based on physical appearance, genealogy, and the performance or possession of the privileges of whiteness. ${ }^{\prime 34}$

In the decades before the Civil War, state laws thus attempted, sporadically, to employ a rhetoric in which one drop of black blood made a person black, well before its formal systematization in the early twentieth century. What role did advertisements for runaway slaves passing as white play in enhancing or undermining the ideology of the one-drop rule? Indeed, some of these very questions about what whiteness is, what blackness is, and who is "purely white" are debated within them. Moreover, especially in the three decades preceding the Civil War, there is an anxious attempt in these advertisements to pinpoint something like a racial essence - something that makes a person "two-thirds white" but not "pure white," or something that would allow an observer knowledgeable about racial difference to detect the "one drop" of black blood. Yet the discourse often contradicts itself by failing to pinpoint the trait that evacuates the enslaved from the category of whiteness. These documents also evince knowledge that passers can easily fade into the white population at large once free, and so some of the documents subtly manifest fear that the passer him- or herself actively threatens the idea of white racial purity. Racial passers put pressure on the notion of the one-drop rule by seeming to challenge the idea that black racial ancestry is detectable, visible, or even present after a certain number of racial intermixtures have occurred. Some of the advertisements indicate that there is, in fact, no difference between someone who is white and "nearly white," while others attempt (especially in the decades preceding the Civil War) to cling to the ideology that a single ancestor makes an individual black (and therefore inferior to whites), even in the face of their ability to pass. Yet ideological thinking about racial fixity is uneven, so the advertisements cannot always be categorized neatly from a historical perspective. It is from within the gaps and slippages of this ideology that challenges to it emerge.

\section{Debating the Agency of the Pass: Intentional or Not?}

Some of these historical controversies about what race signifies are embedded in the question of how intentional the passing of the runaway slave is - and to what extent the runaway controls and manipulates his or her production of a white racial persona. Passing for white and free when one is considered by the law and society to be black and enslaved often involves a complicated performance, as well as an awareness of the physical, linguistic, social, and legal protocols that create racialized identity. Looking back on these documents in an era that acknowledges that racial identity is (in large part) performative, one sees all kinds of agency in these passing dramas. Masters, however, sometimes appear more befuddled about to what extent their property is capable of using and manipulating the conventions of racial and class identity toward a perfor- 
mance that enables their freedom. Many masters viewed blacks as childlike and inferior mentally to whites and so refused to acknowledge the evidence of intelligence, agency, and skill embedded in all kinds of activities of enslaved life. ${ }^{35}$ Within the advertisements for slaves who escaped by passing, some masters appear to admire the enslaved's ability to command and control the signifiers of racial identity, while other advertisements betray a patent attempt to read a kind of accidentalness or lack of intentionality back into these performances, in the face of evidence to the contrary.

For example, an advertisement posted in the Virginia Gazette on September 17, 1770, narrates ambiguity about how much control one slave exhibited in his manipulation of the codes of race and class: "Run away from the subscriber, near Fredericksburg, a light mulatto man (who may easily pass for a white man) named Jack, though very probably he may change his name to John Wilkson, about 5 feet 6 or 7 inches high, and well made; had on when he went off a brown fustian coat, canvas waistcoat, and light coloured cloth breeches." ${ }^{" 36}$ With his nice clothing and light skin, Jack (who may change his name to John, perhaps to better pass) "may easily pass for a white man," states the advertisement — but does he exactly decide to pass for white (and presumably middle class)? The discourse neither confirms nor denies the agency of the pass, even though the changing of names is often allied with some sort of passing. Almost the exact same language is employed in this same journal thirteen years later to describe another slave: "Thirty dollar reward. ... Osbourn ... white enough to pass for a white man. ${ }^{37}$ Whether Osbourn controls the agency of the pass remains unclear throughout this advertisement.

More than seventy years later, the question of the passer's control over his or her passing performance is still debated in these advertisements. An unusual advertisement for a runaway twelve-year-old boy appeared in the Columbus, Georgia Tri-Weekly Enquirer on March 14, 1857. "I will pay $\$ 25$ for the apprehension of a small negro boy named Walter ... very bright mulatto, small features, gray eyes, has a down look when spoken to, when talking the brogue peculiar to South Caroline negroes," writes the owner, Van Marcus. The boy is marked as "negro" linguistically (by his brogue), and the owner has "reason to believe that the boy was aided or carried off by some white person." ${ }^{38}$ Yet the last line of the advertisements complicates this: "The boy will no doubt endeavor to pass for a white boy." If the boy was "carried off by some white person" this implies an involuntary escape (perhaps a kidnapping by a white abolitionist, a claim made frequently by white masters), yet his owner grants him volition over the actions when he says "the boy will no doubt endeavor to pass for a white boy." Category crisis is evident in the advertisement, as the owner both does and does not believe that his slave would be intelligent enough to escape or pass for white on his own. A fictional parallel might be drawn to Charles Chesnutt's short story, "The Passing of Grandison" (1899), which is set in the early $1850 \mathrm{~s}$; in this story the central character Grandison claims to have been kidnapped (while in the North) by white abolitionists, who take him 
to Canada and try to free him. However, he claims that he steadily made his way back to his master's plantation, where he is fêted by his master (Colonel Owens), who takes at face value his story that he was "carried off." Just a few weeks later, however, Grandison escapes with his entire family-apparently having used his time in the North to prepare a route on the Underground Railroad to Canada. Owens is fooled by Grandison's subservient and even Sambolike demeanor in the same way that Van Marcus seems to be duped by Walter's brogue and "down cast" look into thinking —or perhaps hoping - that his slave was decoyed off by some abolitionist. ${ }^{39}$ Yet the last line of the advertisementthat Walter will "no doubt endeavour to pass for a white boy"- betrays awareness that something more exists behind the downcast look and broken English of this young boy.

Slave owners also seem puzzled at times about how deliberate a deception their slaves might have undertaken in escaping and in passing for white. This perplexity intersects with a key concern in passing discourse of the past and present about whether passing involves some deliberate level of deception or can be merely accidental. For example, sociologist Brooke Kroeger defines passing as "when people effectively present themselves as other than who they understand themselves to be. ... Passing involves erasing details or certain aspects of a given life," ${ }^{40}$ and legal scholar Randall Kennedy offers a similar definition: "passing requires that a person be consciously engaged in concealment." ${ }^{\prime 41}$ Yet many literary passing narratives from the nineteenth century turn on a passer who does not know his or her "true" racial ancestry, and so passes for white for many years without conscious knowledge of this passing behavior. Lydia Maria Child's “The Quadroons" (1840), Hannah Crafts's The Bondwoman's Narrative (ca. 1853-61), William Wells Brown's Clotel (1853), and Frances Harper's Iola Leroy (1892) feature individuals who do not know for some portion of the narrative that they descend from a black mother who was herself enslaved and so are (in effect) accidentally passing as white. ${ }^{42}$

Perhaps most useful, then, in trying to consider the agency of the pass and/or the passer's level of deception is the work of the late sociologist Erving Goffman, who viewed passing as a range of behaviors such as "unwitting passing that the passer never learns he is engaging in," "unintended passing that the surprised passer learns about in mid-passage," "passing during nonroutine parts of the social round," passing "during routine daily occasions, such as work," and/or "disappearance"- - complete passing over in all areas of life, the secret being known only to the passer himself." ${ }^{43}$ Referring this back to advertisements for runaway slaves, some masters may have clung to any shred of evidence suggesting that these near-white individuals passed only unintentionally, by accident, as it were, instead of granting them control over the racial performance and the intelligence often required to enact it.

It is indeed quite striking how often these advertisements use ambiguous and conditional language concerning whether the passer is or is not deliberately passing for white and is or is not engaged in a purposeful and premeditated 
deception. The Maryland Journal and Baltimore Advertiser from September 3,1782 , posts an advertisement for a runaway slave named Jack, "a very white mulatto, short and well set, freckled and has gray or blue eyes, short light hair curling in one row, thick stubbed nose; his other features are strong, and his face rather large for his stature." After such close attention to physiological and physiognomical details, the advertisement then goes on to describe his clothing, his trade as a weaver and shoemaker, and the items he carried away with him, only to conclude enigmatically, "He will pass very well for a white man." 44 Does he try to pass? And what might this trying to pass entail? Such vague language is used throughout the period, across a wide range of geographical regions:

South Carolina Gazette, June 25, 1772: Run away the 22d Instant, June, a Mulatto young man, named Jack, about 20 years of age ... has light brown hair, and may pass for a white man. ${ }^{45}$

Federal Republican and Commercial Gazette [Baltimore], February 24, 1810: Sixty Dollars Reward. ... Jack is so light a mulatto that he might pass for a white lad, unless particularly noticed. ${ }^{46}$

Baltimore Patriot and Mercantile Advertiser, April 5, 1828: Ran away from the subscriber last Tuesday a very bright $\mathrm{Mu}-$ latto Boy, called Robert. ... Bob is very near white, so much so that at a little distance he would pass for white. ${ }^{47}$

Macon Daily Telegraph, June 15, 1860: \$20 Reward. I will pay the above reward for the apprehension of Martha and Celia, who absconded last night. Martha is a Mulatto Woman about 30 years old, orange color, straight hair, and walks a little lame. Celia, her daughter, is about 11 years old, a bright mulatto, can pass for white. ${ }^{48}$

As already noted, passing for white often entailed manipulation of complicated sets of signifiers involving names, clothing, appearance, speech, and other details, so when a master says his slave "might pass," "may pass," "would pass," or "can pass" for white, he seems to be understating the sophisticated intelligence involved in such a performance.

Some masters also aver that their slaves can pass for white unless they are carefully examined; in so doing they once again raise questions about how intentional the passing performance is. An advertisement from the Maryland Journal and Baltimore Advertiser in 1785 comments that the "remarkable white mullato [sic] Slave" James "will pass for a white man without close examination" 49 without going into details; in what ways the "white mullato Slave" is "remarkable" also remains enigmatic. As Sollors discusses, a wide variety of texts held that there were a few key tell-tale traits to determine a black racial 
identity in the absence of dark skin, such as dark moons on the fingernails, a certain luminosity to the irises or a yellow tinge to the whites of the eyes, or hair at the base of the neck or elsewhere that had a certain kink. ${ }^{50}$ The owner of James implies that a person who knows to look closely for such tell-tale markers might find them in James. But does James conceal racial markers by (for example) closely trimming his hair, wearing gloves or eyeglasses, or donning a wig? This is left ambiguous. Again and again this language of "close inspection" is repeated, especially around the area of New Orleans, where interracial sexual relations had been so common as to produce a class of enslaved individuals who looked entirely white:

The Daily Picayune [New Orleans], March 10, 1854: Ran away last evening. ... Sarah Marshall, a light mulatto girl about sixteen years of age, with blue eyes and black hair, and might easily pass for white if not closely inspected. ${ }^{51}$

Daily Picayune [New Orleans], July 7, 1855: Ran away-the Negro boy Tom, aged about 22 years. He is a bright mulatto and could pass for white, if not closely noticed. ${ }^{52}$

Masters here attempt to stabilize the idea of whiteness by implying that it can be separated from blackness in some way (by "close inspection"), although they leave the means of detecting this blackness unwritten.

A discourse in which the passer is not exactly white, and is not exactly granted control over the performance of the pass, is therefore common. Several advertisements from the period 1830-60 stand out in particular, however, for their attempt to adhere rhetorically to an ideology in which the enslaved person, no matter how white-looking, is still always black. The first was published in Delaware in 1834:

People's Press [Wilmington], November 12, 1834: \$100 Reward will be given for the apprehension of my Mulatto Man Jo. ... He is two thirds white, and when cleanly dressed, "might pass" for a white man. ${ }^{53}$

On the one hand, Jo's master refers to him as "two thirds white." But on the other hand, by putting the phrase "might pass" into quotes and italics, he seems to indicate skepticism about how well Jo can indeed truly and successfully pass for a white man. A similar degree of linguistic ambiguity appears in the following advertisement, published in Memphis in 1860:

Memphis Weekly Appeal, April 18, 1860: \$500 REWARD. Ranaway from the subscriber, about the 27th February last, a certain mulatto boy about 18 years old named DAN. Said boy is nearly white, sandy hair, weighs 155 pounds - about five 
feet eight inches in height, has good teeth, good countenance, and would nearly pass for a white person — has black eyes. ${ }^{54}$

Dan is "nearly white" and can "nearly pass for a white person." It is very difficult to locate or pinpoint the racial difference that marks him as "not white," yet he does not quite slip into the category of whiteness, as Fanny appears to do. The logic of racial ideology is troubled here, but not annihilated, as it seems these advertisements cling to ideas of racial difference that separate these nearwhite individuals from "pure" white ones, and makes their passing performance detectable in some way.

\section{Passing for "White": Intentionality Granted (But Not Whiteness)}

On the other hand, many advertisements indicate quite clearly that the enslaved individual intentionally passes for a white man or woman. The earliest example of passing's usage in a racial sense that I have located comes from a 1747 New York newspaper:

The New-York Weekly Journal, no. 701, May 25, 1747: Made his escape from on board the Privateer Brig, Pollux, on the 20th inst, a Mulatto man named Storde, a Bermudian Born, aged about 23 years ... pretty fair, with his Head commonly shaved in order to make himself pass for a white man, by trade a carpenter; the cloathes he used to wear before he left the vessel, was a check'd shirt, a striped Flannel Jacket, a pair of Oxnabrig trousers, a red and white worsted cap, and some other cloathes. ... He carried with him both shoes and stockings, with a large pair of silver shoe buckles and a silver stock buckle and also a pair of Gold Sleeve Buttons, when in Bermuda, which without doubt he had with him, and which, 'tis thought he will offer to sell. It is very likely that he may be well dress'd as he had good cloath when he left Bermuda. ${ }^{55}$

The intentionality of the slave to pass racially seems clear; it is said that Storde has his head "commonly shaved in order to make himself pass for a white man," perhaps to disguise hair that was too wavy or coarse to be considered "white." Indeed, attention to hair as a feature in these advertisements is obsessive; when skin does not reveal racial identity, it is clear that hair might function as another signifier for decoding or detecting race. The advertisement also manifests awareness that not only racial features, but also class-based ones, construct a slave's identity as chattel, as a piece of property rather than a property owner; Storde escapes with "both shoes and stockings" and with gold sleeve buttons and silver buckles that he will either sell or use to create new clothing. 
"It is very likely that he may be well dress'd as he had good cloath when he left Bermuda," comments the advertisement. Presumably, Storde left with this cloth and with the intention of sewing himself new clothes. Storde is here granted enough agency to understand and manipulate codes of class, property owning, and prosperity, even as he is reinscribed as chattel, as a piece of black property. "Ten pounds" it is said, will reclaim the property, "the said Mullato slave."

Another early advertisement that grants the enslaved agency over the pass was published in 1773. "Run away from Etham, on Sunday the 20th of Jan last, a light Mulatto Fellow named OTHO ... with a freckled Face, light gray Eyes, brown Hair tied behind, his Skin under his clothes very white, had on a blue Cloth Coat and Waistcoat with a red Velvet Cape, and I expect will endeavour to pass for a white Man" reads an advertisement from the Virginia Gazette on February $18,1773 .{ }^{56}$ Under his clothes Otho is described as "very white"-perhaps his master had him out in the fields to darken this whiteness. But Otho will uncover this whiteness and "endeavor to pass for a white man"; the linguistic focus appears to be on the slave's effort to pass for white. Prior to the Revolutionary period, as noted, whites were kept in forms of long-term indentured servitude, and Otho's master does not seem concerned about whether his slave is or is not white.

Many advertisements written during the time period when the one-drop rule was being formalized, however, attempt to imply that runaway slaves who intentionally pass are "nearly white" but not "white." For example, the Charleston Courier from August 4, 1820, lists an advertisement for a runaway named Jack Mason (or Jack Jones) who has "sandy, strait hair, and is almost white"; the owner comments that "the fellow no doubt will attempt to pass for a white man, which by the by is nearly the fact, but not free born." ${ }^{57}$ Jack is "nearly" a white man and "almost white," but not "white" and not "free born," so subject to enslavement. A legal status as slave trumps a white appearance, although some category crisis appears in the equivocal phrase "which by the by is nearly the fact" in regards to Jack's status as "nearly" a white man. A similar advertisement from Georgia by the planter Zachariah Booth in 1833 reads:

Stop Mabin!! Runaway from my house in Talbot County, Georgia, on Flint River, on 25th of December last at night a man slave by the name of Mabin, about twenty years old, chunkily built, a bright mulatto, with grey eyes - hair straight and sandy — a great deal on his head and rather bushy. He will pass for a white man where he is not known. ${ }^{58}$

The advertisement implies that where he is "not known" Mabin can pass for a white man, but this passing certainly does not make him white- he is still coded as "mulatto" by the advertisement.

An advertisement from New York in 1783 grants intentionality through the action of pretending to be white, yet also implies that the passer is not truly 
white: "Run Away ... Mulatto, or Quadroon Girl, about 14 years of age, named Seth, but calls herself Sall, sometimes says she is white and often paints her face to cover that deception." ${ }^{59}$ As read by her master, Seth is involved in a performance in which she passes for something she is not-she is a "mulatto" or "quadroon" girl passing for white. While this advertisement does not grant her racial status as "white," it does instate her agency through this performance or "deception." These advertisements therefore show ideology being constantly reinvented, for no matter how "white" these men and women are or pretend to be, rhetorical markers are put into place that still mark them as "black" escaped slaves.

\section{Passing for Free and White}

As discussed above, passing for white and passing for free often are interconnected. Especially after the American Revolution, when blacks gradually became the only permanently enslaved labor pool, a white appearance could be important as a marker of free status. It is no surprise, then, that many advertisements entwine whiteness (light skin or fair complexion) with passing for free:

Virginia Independent Chronicle [Davis], July 9, 1778: Runaway ... a likely mullato woman, called Rachel; about 25 years of age. ... She is an excellent seamstress, and probably will pass (from being uncommonly white) for a free woman, unless closely observed. ${ }^{60}$

Annapolis, Maryland Gazette, July 20, 1786: Ran away ... a mulatto slave named Toney, a very likely, well made, active fellow ... he will probably attempt to get to Baltimore and pass as a free man, from his color. ${ }^{61}$

Charleston, City Gazette and Daily Advertiser, June 4, 1821: Ranaway ... two Negroes: the one, a yellow fellow, named Randall ... The other, his wife, named Ann. ... N.B. As the above Negroes are of light complexion, they may attempt to pass as free. ${ }^{62}$

Charleston, South Carolina State Gazette, December 20, 1830: Ranaway. ... Sophia ... fifteen years old. ... a bright mulatto, with remarkably straight hair. ... From her colour and appearance, she may be supposed to be free and no doubt will endeavor to pass herself as such. ${ }^{63}$

It seems, then, that passing for free was often strongly marked as racial passing, passing (at least temporarily) out of blackness and servitude and into whiteness and freedom. Of course, as Amani Marshall reminds us, "in passing for free, runaways relied on more than just their complexions," but Marshall 
also notes that "passing for free was easier for fair-skinned slaves who were assumed to be white." 64

The nexus between whiteness and freedom suggests that while it was theoretically possible to be black and free, grave limits were placed on the freedoms allowed to blacks as a class. Free blacks enjoyed only limited legal rights in virtually all states; even states that had banned slavery often refused to extend to free blacks rights associated with full legal citizenship such as voting, serving on juries, or testifying in court. ${ }^{65}$ Moreover, insurrection was a significant fear in the early decades of the nineteenth century, because of revolts by Gabriel Prosser (1800), Denmark Vesey (1822), and Nat Turner (1831), as well as the publication of David Walker's fiery Appeal (1829). Such events ultimately led to a tightening of rules and laws limiting the freedom of movement, gathering, literacy, and other activities of blacks in both the North and the South. In such a context, the equation between white skin and freedom became more robust; even though laws in many states technically allowed for black and free individuals, the reality was often far different.

Fictional and nonfictional literary texts from this period can also shed light on the connections between whiteness and freedom by amplifying the somewhat cryptic discourse of these advertisements. In 1848, Ellen Craft passed for white and male to escape from slavery; her darker-skinned husband, William, escaped with her by passing as her slave. ${ }^{66}$ The implication of their narrative is that Ellen Craft's performance of whiteness is the key to freedom for both individuals, while her performance of masculinity is only to insure her safety while traveling. Yet it also needs to be noted that William Craft- too dark-skinned to pass for white - successfully passed as her slave to enable the couple's travel to the North.

Passing for white and free are also intertwined in one of the earliest novels to use the passing trope-Richard Hildreth's The Slave; or, Memoirs of Archy Moore (1836). Here the protagonist, a "white negro," successfully escapes from slavery by passing as a free man both racially and in terms of his class status; that is, he looks white but also possesses some of the necessary attributes that code him as white and propertied, such as "good clothes, and as much learning as an overseer." One of Archy's fellow slaves-Thomas - is darker-skinned and so explicitly refuses to run away with Archy: "You can readily pass for a free man. ... If I go with you, we shall both be stopped and questioned. ... We shall certainly be taken." Thomas's logic foreshadows cases such as Dred Scott v. Sandford (1857) when he argues, "It is a great way to the free states, and I have little chance and no hope of ever getting there; and if I did, what should I gain by it? ... But you, Archy, you can do better." ${ }^{\text {67 }}$ Juridically free blacks were often treated as inferior, noncitizens with few legal rights, so freedom means little to Thomas and he opts to become an outlaw instead.

Although not a case about passing per se, Dred Scott v. Sandford casts light on the connection between whiteness and various types of social and legal privilege in the years leading up to the Civil War evident in both advertisements 
for runaway slaves and literary texts. In 1846 Dred Scott sued for his freedom on the grounds that although he and his wife Harriet were slaves, they were entitled to their liberty because they resided in Illinois and the Wisconsin Territory, geographical areas in which slavery was illegal. In 1857 the United States Supreme Court ruled against Scott, finding that neither he, nor any person of African ancestry, could claim citizenship in the United States. What is most salient for a discussion of passing is the idea that the presiding judge-Taneyputs forward about an absolute and perpetual black legal and social inferiority; black Americans are ruled to be "a subordinate [60 U.S. 393, 405] and inferior class of beings, who had been subjugated by the dominant race, and, whether emancipated or not, yet remained subject to their authority, and had no rights or privileges but such as those who held the power and the Government might choose to grant them." ${ }^{68}$ Whether free or enslaved, a line is drawn by this decision between blacks (an inferior, oppressed, noncitizen race) and whites. This means, then, that for the racial passer, claiming a form of whiteness was vital to a successful escape as well as (possibly) to continued freedom once he or she had reached safe territory.

\section{Passing as Native American or White Nationalities}

The meaning of whiteness itself, however, was not always clear, and some slaves escaped by exploiting connections to Native American ancestry (considered in many states to be free) or by passing as a European national. Before looking at these specific advertisements, however, it is useful to consider one court case that might amplify the meaning of these brief documents. An important legal explication of this behavior can be found in Hudgins v. Wright (1806), where a status as Native American led to freedom for a group of enslaved women. According to Ariela Gross, this case was one of the most influential trials in setting a Southern precedent for slave/free status on the basis of race. ${ }^{69}$ Haney López concurs, arguing, "Hudgins tells us one is Black if one has a single African antecedent, or if one has a 'flat nose' or a 'wooly head of hair." goes on to explain, under southern law in most states, "Blacks were presumably slaves and thus bore the burden of proving a free ancestor; Whites and Indians were presumably free and thus the burden of proving their descent fell on those alleging slave status." $" 71$

In advertisements for black runaway slaves, there are many examples of exploiting a connection to a Native American ancestry or to nationalities considered to be "white." "RAN away from the Subscriber ... his Mulatto Waiting Man, named Jem, about 28 or 30 years of Age," reads an advertisement from the Annapolis Maryland Gazette on October 20, 1763. The advertisement goes on to describe in detail an individual who knows how to pass for Indian, for several tradespersons, and for free: 
A well-set Fellow, wears his own black Hair, which is commonly tied in a Cue behind, or platted, and curls on each Side of his Face. Had on when he went away, a Cotton Jacket, Brown Roll Trousers, and old Shoes; but, it is supposed, he will change both his Name and Dress, as he has been seen with his Hair comb'd out straight, and an Indian Match coat on: I am informed he intends to make his Escape in that Disguise, pass for an Indian, and profess himself a Shoemaker. $\mathrm{He}$ is well acquainted both in Maryland and Pennsylvania, and is a very handy, sly, complaisant, smooth tongued Fellow, can shave and dress a Wig as well as most Barbers, and will (as he is a light Mulatto) probably pass for a Freeman, and profess himself of that Trade. ${ }^{72}$

The discourse that seeks to re-enslave Jem as a piece of property also reinforces his resourcefulness, intelligence, and knowledge. It seems that Jem could pass as Indian by braiding his hair, as a freeman by changing his clothes, and as either a barber or shoemaker by brandishing the various tools of these trades. ${ }^{73}$ If this individual dresses and looks like an Indian, implies the owner Waggaman, he may be able to blend in with the "Back Indians," a tribe of Indians in Maryland known as the Susquehannock.

Passing for white is also sometimes conjoined with passing for Native American. Peter Youngblood ran away from his owner Captain Easterby and was advertised in the Charleston Courier on April 7, 1831. "Peter [has] ... very light complexion, straight black hair, rather slim and pale," says the advertisement. He can also manipulate the codes of race and class: "When well dressed looks very genteel, but might be taken for an Indian, or might pass either for a free or white person, as he can invent quite plausible stories of himself." Finally, he will certainly portray himself as a tradesperson of some sort: "Said Peter Youngblood is very ingenious, and has been in my employ as a dyer and scourer; he has a great liking for tailoring, and knows something of it." ${ }^{74}$ What comes through in the advertisement is the sense of a resourceful, intelligent, capable person who can "invent quite plausible stories of himself" - stories that generate multiple, and mutating, identities as a free person, a white person, a Native American, a tailor, and a cloth maker. ${ }^{75}$

One final example in which a slave passes for free, upper class, French, and white illustrates, again, the level of control over the passing performance that is sometimes embedded in these documents. In May of 1794, a "mulatto" slave named Joe Cully ran away from his master, who then advertised him in detail in the Virginia Herald and Fredericksburg Advertiser. Offering a twenty dollar reward for this "very bright and much freckled ... very genteel made, spry, active fellow," Joe Cully's owner comments that Joe escaped with "three white shirts, one brown ditto, a pair of satinet breeches dyed purple, a pair of country jeans ditto, dyed nankeen colour, [and] one swanskin waistcoat, striped." ${ }^{.76}$ Escaping 
with clothing that could mark him as an upper-class gentleman, Cully demonstrates a sophisticated awareness that not only his race, but also his class, could subject him to enslavement. Finally, Cully's owner notes that he "endeavours to pass as a Frenchman, and alters his tongue to a broken language that may be very perceivable to anyone that should converse with him." With his various sets of apparel, his light skin and freckles, his multilingual abilities, and his genteel persona, Joe Cully can pass for a free, white, upper-class, French gentleman, not the impoverished black slave that he in fact is, or so the advertisement implies. In this advertisement, the master seems to be in some degree of category crisis, as whiteness is shown to be more performative than real-a matter of clothing, speech, and activities. Furthermore, by the very detail in which Joe Cully is carefully described, the owner appears to validate him as a skillful, intelligent subject. At the same time, the advertisement seeks to reenslave Cully specifically as an item of property, an escaped slave inferior to, and lacking coequal status with, white men.

\section{Passing as White and Married: Families Passing for White to Escape Together}

Marriage occurred under slavery but had no legal sanction, and in most states (with the exception of Pennsylvania and Massachusetts) miscegenation was banned at least until the Civil War; indeed, as late as 1969, marriages between whites and blacks were outlawed in some states. ${ }^{77}$ Prior to the Civil War, a marital state therefore sometimes became interlinked with a status as free and (sometimes) white. In some cases one partner was in fact technically free (and white) while the other was enslaved and black, as this advertisement illustrates:

Virginia Gazette, March 17, 1774: Run away from the subscriber, in Cumberland county, on the 26th of February a Mulatto man slave named SANCHO, appears to be about 40 years old, stoops a good deal, and is by trade a carpenter and cooper. ... Absconded with him a white servant woman. ... I expect they will change their names and endeavor to pass for husband and wife, as free people. ${ }^{78}$

The structure of the advertisement implies that the whiteness (of the "servant woman") allows marriage, which then allows freedom. Moreover, it seems that Sancho, too, would be passing for white, because an interracial married couple traveling through Virginia in 1774 would arouse great suspicion. Similarly, in the Maryland Journal and Baltimore Advertiser from February 6, 1781, Barbara Williams offers an incredible amount of money - a "Four Thousand Dollars Reward"-for her "white Mulatto slave, named Leonard" who was "persuaded off by a white woman, who calls herself Rachel Dorsey." Williams goes on to state that "it appears that she had two children by the above slave" 
and that "it is supposed they will pass for man and wife, and make for Pennsylvania or the Eastern Shore." ${ }^{79}$ Although the advertisement does not say this, again, it seems the "white mulatto slave" Leonard will also pass for a white man, at least until he reaches Pennsylvania, where mixed-race marriage was allowed.

Like William and Ellen Craft, enslaved black couples sometimes escaped together. In one striking 1826 example, a married couple used passing for white to obtain freedom; an enslaved woman named Linda, whose owner believes that she "might be taken by a stranger for a white woman, and may attempt to pass as free" describes how she escapes with her darker husband, Tom. Apparently Linda enlists a British man to pose as her husband, and Tom travels with them as their servant. ${ }^{80}$ In Georgia in 1855, another couple ran away together and passed off the darker member of the duo as "property":
Ranaway from the subscriber on the 20th inst. A yellow boy named Rufus. ... Also a mulatto woman named Margaret Green. She was well dressed, had on a bundle of fine cloth- ing, and I believe she is now making her way to Columbus, and will no doubt pass for white, having but one-eighth negro blood in her, she having decoyed the boy off will, in all prob- ability, pass him off as her property. ${ }^{81}$

Both Margaret and Rufus are granted a high degree of perspicacity in the advertisement; Rufus is "a fine and intelligent boy," and Margaret is clever enough to utilize her nice clothing to pass as an upper-class woman traveling with her "property." Yet she herself is "property." The advertisement also manifests uncertainty about Rufus's alliances. It says that Margaret has "decoyed the boy off," which appears to remove his agency, but being "passed off" as someone else's "property" certainly indicates a degree of complicity in this plan on Rufus's part.

Individuals who could pass for white also sometimes helped their siblings who could not, at times exercising extraordinary skill in doing so. One fascinating pair passing was published in the Charleston Courier on July 30, 1849, and is worth quoting in detail:

Fifty dollars reward-Runaway from Savannah, on the 6th July, 1849, my Mulatto man Patrick; his color is very bright, straight hair, color of deep red, 5 feet 8 or 9 inches, age 24 or 25 years, slim build, cooper by trade. He left in company with his brother, who goes by the name Adam Mendenhall, a barber by trade. Adam is a darker Mulatto than Patrick; round shouldered, hair black and inclined a little to curl. He is 45 years of age, and may, from his trade being a barber, endeavor to alter their hair by coloring or wearing a wig. They 
may endeavor to pass for white or free person, as Adam is a very intelligent negro, and can read and write. Patrick can do neither. ... The above named boys went off in a wagon, as pedlars; Adam is also a runaway, and Patrick is acting as his waiting man. ${ }^{82}$

Beyond their ability to "pass for white or free persons," the advertisement also notes how they will (perhaps) dye their hair and wear wigs; Adam may also pass as a peddler, and Patrick may pass as his apprentice or manservant. Adam can read and write and is also described as "very intelligent." Whiteness is explicitly shown to be something that can be performed by clothing, literacy, wigs, trades, and (perhaps) the careful use of some face powder. The advertisement as a whole seems to indicate that the owner's conception of what makes a white man different from these two intelligent, resourceful, near-white individuals may be in crisis. Moreover, these men resist the way their bodies would be surveilled and demarcated in print forms such as newspapers. "Resistance," comment Gwenda Morgan and Peter Ruston, "is produced through the deliberate control of visibility"; "power demanded visibility, but this was not always forthcoming. ${ }^{83}$ These two men engage in a range of behaviors that frustrate the public's ability to see and know their visible bodies as black or enslaved. They formulate a series of metamorphosing identities that stand in opposition to a monolithic status as black, enslaved property.

\section{Conclusion: Advertisements for Runaway Slaves as Counter-Hegemonic}

What inferences can be drawn from this data? First, while these advertisements demarcate questions about the meaning, validity, and construction of whiteness and blackness, as well other ethnic identities, they also articulate questions about whether categories of racial identity are "real" and defining of an individual in some way, or, conversely, masks and roles that can be performed (or not), as the individual desires. The documents also complicate unitary notions of racial identity, and therefore the idea that being "true" to one's "real" racial identity is unproblematic; both the owner of the slave (through the discourse of the advertisements) and the passing subject (through his or her behavior) at times delineate the multiplicity and instability of racial identity and allegiance. Questions of whether the racial passer denies his or her (one) "true race" by passing for white and whether passing troubles a black-white racial binary are still present in contemporary debates about the behavior. ${ }^{84}$ However, it is uncertain whether these individuals who passed for white or Native American or French truly believed themselves to be white or Native American or French. While it is clear that many deliberately changed or occluded racial and class signifiers that marked them as black and enslaved, in so doing they might have been simply expressing their sense of selfhood. In The Woman Who 
Pretended to Be Who She Was: Myths of Self-Imitation (2005), Wendy Doniger discusses the ways individuals in the past and present perform roles that they truly become or even initially perceive themselves to be, in the face of a society that labels them otherwise ${ }^{85}$ So might it be with the racial passer, who runs away from slavery by inhabiting a "false" self and racial identity, or perhaps by only pretending to be what he or she "really" believes himself or herself to be. In playing up multiple sides of their identities, these individuals may come to possess more fully their own lived, perceived, or implicit sense of selfhood.

Second, whiteness, in particular, seems to be in category crisis in these documents. In these advertisements, masters struggle (and often fail) to define their slaves who can pass for white as white-looking but not-quite-white. Runaway slave advertisements reveal, as Waldstreicher notes, the ways in which slaves capitalized on the expectations of the masters by contravening their expected social positions, and the ways the masters struggle to replace the slaves in expected roles ${ }^{86}$ This applies to the enslaved individual's whiteness as well, however. Masters qualify, recast, and rescind the notion that their slaves are almost white or white to force passing escaped slaves back into the paradigm of the nonwhite, from which they appear to have absconded. Yet at times racial ideology itself seems to be ruptured in these advertisements to the point where it is difficult to repair it as a fulcrum for enslavement. The owner of Fanny, for example, appears to be wondering what whiteness really is (if Fanny is "as white as most white women"), and the owner of Joe Cully seems to be questioning what does indeed make a white, free, upper-class man. The owner of Jack Mason admits that it is "nearly the fact" that his slave is "a white man" and can only recast him as enslaved based on a legal status as "not free born." Billy G. Smith's work argues that runaway slaves in the mid-Atlantic created a destabilizing situation and that their actions are comparable to slaves who revolted in the South and the Caribbean. Individualistic acts of running away ultimately put massive pressure on the system of slavery. ${ }^{87}$ This pressure also can be heard in advertisements that describe various kinds of racial passing, where whiteness itself seems to be under assault and even erasure in the face of escaped slaves condemned to perpetual enslavement who are, nonetheless, as white as any white woman or man who is free.

Finally, while this discourse certainly has a hegemonic origin, in that it is an attempt by white slave owners to "out" a slave who can pass for white, it also sometimes speaks in a counter-hegemonic way, enunciating a detailed portrait of an individual who is explicitly not a bestial black object, or a thing, but a fully humanized subject. It becomes very clear in these documents that the enslaved "property" has multiple and diverse skills that allow him or her to express various incarnations of selfhood as upper class, propertied, white, Indian, married, and free, as well as various tradespeople or nationalities. In fact, the "property," the possessed, appears at times to be no different, either physically or mentally, from the owners. Advertisements for runaway slaves that have as their goal re-enslavement of a debased other therefore sometimes grant these 
very others' subjectivity, depicting them as rational and intelligent human beings who can perceptively manipulate the legible and illegible protocols that create racial, class-based, and social identities. If race is an ideology that must be continually recreated, this very process is also at work in the advertisements themselves, which anxiously attempt to shore up racial difference, even in the face of an evident failure to demarcate individuals along clear-cut and unchanging racial lines.

\section{Notes}

1. In deference to usage during this period, throughout this essay I employ the term "black" (rather than the more modern term "African American") to designate individuals of African descent residing within the colonies or the United States.

2. Parish Transcripts, Box II, bundle: S.C., Minutes of House of Burgesses (1730-35), 9, discussed in Winthrop Jordon, "American Chiaroscuro: The Status and Definition of Mulattoes in the British Colonies," William and Mary Quarterly 19, no. 2 (1962): 189.

3. Henry Laurens to William Drayton, February 15, 1783; see David Duncan Wallace, The Life of Henry Laurens (New York: Putnam, 1915), 454.

4. Winthrop Jordan believes both Gideon Gibsons were passing ("American Chiaroscuro" 191), while Daniel Sharfstein believes that neither Gibson passed for white (see The Invisible Line: Three American Families and the Secret Journey from Black to White [New York: Penguin, 2011], 2-26). However, it seems clear from the language used by contemporaries that the Gibsons were viewed as passing into whiteness: "The children of this same Gideon having passed through another state of Whitewash were of fairer complexions than his prosecutor George Gabriel [Powell]" (Wallace, Life of Henry Laurens, 454), writes Laurens, a slave owner himself.

5. Letter to Louis Kossuth, Concerning Freedom and Slavery in the United States (Boston: R. F. Walcutt, 1852), 12.

6. Mark Twain, The Tragedy of Pudd'nhead Wilson: And the Comedy of Those Extraordinary Twins (Hartford, CT: American Publishing Company, 1894), 33.

7. According to Werner Sollors, Nathan Huggins coined the phrase "Passing is Passé" as the title of an essay written in the early 1970s in his book Revelations: American History, American Myths; see Neither Black nor White yet Both: Thematic Explorations of Interracial Literature (New York: Oxford University Press, 1997), 508. However, the phrase has also been used more recently in Paul Spickard's Mixed Blood: Intermarriage and Ethnic Identity in Twentieth-Century America (Madison: University of Wisconsin Press, 1989). For studies that view passing as primarily occurring from 1850 to 1940, see Steven Belluscio, To Be Suddenly White: Literary Realism and Racial Passing (Columbia: University of Missouri Press, 2006); Juda Bennett, The Passing Figure: Racial Confusion in Modern American Literature (New York: Peter Lang, 1996); Gayle Wald, Crossing the Line: Racial Passing in Twentieth-Century U.S. Literature and Culture (Durham, NC: Duke University Press, 2000); and Teresa Zackodnik, The Mulatta and the Politics of Race (Jackson: University of Mississippi Press, 2004).

8. Matthew Frye Jacobson, Whiteness of a Different Color: European Immigrants and the Alchemy of Race (Cambridge, MA: Harvard University Press, 1998), 73.

9. Ian F. Haney López, "The Social Construction of Race: Some Observations on Illusion, Fabrication, and Choice," Harvard Civil Rights-Civil Liberties Law Review 29, no. 1 (1994): 7.

10. My archive was created from the following print sources and websites: Graham R. Hodges and Alan E. Brown, eds., "Pretends to Be Free": Runaway Slave Advertisements from Colonial and Revolutionary New York and New Jersey (New York: Garland, 1994); Billy G. Smith and Richard Wojtowicz, comps., Blacks Who Stole Themselves: Advertisements for Runaways in the Pennsylvania Gazette, 1728-1790 (Philadelphia: University of Pennsylvania Press, 1989); Lathan A. Windley, comp., Runaway Slave Advertisements: A Documentary History from the 1730 s to 1790, 4 vols. (Westport, CT: Greenwood, 1983); Thomas Costa, comp., The Geography of Slavery in Virginia, http://www2.vcdh.virginia.edu/gos; Readex, America's Historical Newspapers Including Early American Newspapers Series 1-6, 1690-1922 and Hispanic American Newspapers, 1808-1980, http://infoweb.newsbank.com; and UNC Digital Collections, North Carolina Runaway Slave Advertisements, 1751-1840, http://libcdm1.uncg.edu/cdm/landingpage/collection/RAS.

11. For discussion of some of the different valences of "passing for" versus "passing as," see P. Gabrielle Foreman, "Who's Your Mama? 'White' Mulatta Genealogies, Early Photography, and Anti-Passing Narratives of Slavery and Freedom," American Literary History 14, no. 3 (2002): 505-39. Because of space constraints, I do not discuss this topic here. 
12. David Waldstreicher, "Reading the Runaways: Self-Fashioning, Print Culture, and Confidence in Slavery in the Eighteenth-Century Mid-Atlantic," William and Mary Quarterly 56, no. 2 (1999): 243.

13. Barbara Jean Fields, "Slavery, Race and Ideology in the Unites States of America," New Left Review 1, no. 181 (1990): 110, 112.

14. See, in particular, Amani Marshall, “They Will Endeavor to Pass for Free': Enslaved Runaways' Performances of Freedom in Antebellum South Carolina," Slavery \& Abolition 31, no. 2 (2010): 161-80, who examines passing for free in these advertisements. Also see Waldstreicher, who focuses on "the acts of cultural hybridization black and racially mixed people committed for their own purposes" that can be seen in these advertisements by looking at clothing, trades, linguistic ability, and ethnic or racial identity $(247-48)$.

15. Neither Black nor White yet Both, 248.

16. See Agnes Smedley, Race in North America: Origin and Evolution of a Worldview (Boulder: Westview, 1993), 26-27. As Smedley remarks, "As it evolved in the nineteenth century, race posed a new dimension of social differentiation that superseded 'class.' Race offered a new mechanism for structuring society based on a conception of naturally fixed, heritable, and immutable status categories linked initially to visible physical markers" (27).

17. I am not, of course, arguing here that all slave masters believed in an essential racial difference that justified enslavement. Yet many did. For example, Thomas Jefferson, himself the father of black children, writes in 1787 that slavery was warranted because blacks "are inferior to the whites in endowments both of body and mind"; see Notes on the State of Virginia, ed. William Peden (1787; Chapel Hill: University of North Carolina Press, 1955), 143. Jefferson's ideas were extremely influential and were used by numerous Southern leaders to justify slavery.

18. Smedley, Race in North America, 119.

19. I borrow here Marjorie Garber's construct of category crisis: "By 'category crisis' I mean a failure of definitional distinction, a borderline that becomes permeable, that permits of border crossings from one (apparently distinct) category to another." Binary categories are sometimes put in question or under erasure by such definitional failure; see Vested Interests: Cross-dressing and Cultural Anxiety (New York: Routledge, 1992), 16-17.

20. Fields, "Slavery, Race and Ideology," 104, 116.

21. Ira Berlin, Many Thousands Gone: The First Two Centuries of Slavery in North America (Cambridge, MA: Harvard University Press, 1998).

22. David Brion Davis, The Problem of Slavery in the Age of Revolution, 1770-1823 (Ithaca, NY: Cornell University Press, 1975).

23. Smedley, Race in North America, 96.

24. For more on the history of white servitude in the colonies, see Don Jordan and Michael Walsh, White Cargo: The Forgotten History of Britain's White Slaves in America (New York: New York University Press, 2008). They argue that in the seventeenth and eighteenth century a huge number of white people were shipped to the colonies for enslavement against their will: convicts, poor or orphaned children ("urchins"), prostitutes, debtors, Irish Catholics, and others; there was also a history of at least 300,000 white voluntary indentured servants being kept in servitude, many for their entire lives (12-16). These practices mainly ceased, they argue, by 1820 (280-81).

25. Daniel J. Sharfstein, "Crossing the Color Line: Racial Migration and the One-Drop Rule, 1600-1860," Minnesota Law Review 19, no. 3 (2007): 597.

26. See, for example, Ingrid Dineen-Wimberly and Paul Spickard, who use this definition in "'It's not that simple': Multiraciality, Models, and Social Hierarchy," in Multiracial Americans and Social Class: The Influence of Social Class on Racial Identity, ed. Kathleen Odell Korgen (New York: Routledge, 2010), 205.

27. For a discussion of these cases, see Ariela J. Gross, What Blood Won't Tell: A History of Race on Trial in America (Cambridge, MA: Harvard University Press, 2008).

28. On the topic of the movement toward the one-drop rule in the decades preceding the Civil War, also see Robert Westley, "First-Time Encounters: 'Passing' Revisited and Demystification as a Critical Practice," Yale Law and Policy Review 18, no. 2 (2000): 313; Joel Williamson, New People: Miscegenation and Mulattoes in the United States (1980; Baton Rouge: Louisiana State University Press, 1995): 98; and George M. Frederickson, The Black Image in the White Mind: The Debate on Afro-American Character and Destiny, 1817-1914 (1971; Middleton: Wesleyan University Press, 1987), 43-49.

29. Lane v. Baker, 12 Ohio 237 (1843); www.lexisnexis.com.

30. Joshua D. Rothman, Notorious in the Neighborhood: Sex and Families across the Color Line in Virginia, 1787-1861 (Chapel Hill: University of North Carolina Press, 2003), 209.

31. "Louisiana Legislature," Times-Picayune (New Orleans), February 2, 1857: 7; Readex, America's Historical Newspapers.

32. Sharfstein, "Crossing the Color Line," 631.

33. Journal of the Indiana State Senate, 43rd Session, 1863 (Indianapolis: Joseph Bingham,

1863), 308; Internet Archive, https://archive.org/details/journalofindiana1863indi.

34. Sharfstein, "Crossing the Color Line," 604. 
35. Throughout the early nineteenth century, blacks were viewed by many as inherently childlike and lower than whites in the so-called great chain of being. For more on how the idea of a childlike black race subtended the notion of white American democracy, see Caroline Levander, Cradle of Liberty: Race, the Child, and National Belonging from Thomas Jefferson to W. E. B. Du Bois (Durham, NC: Duke University Press, 2006).

36. Windley, Runaway Slave Advertisements, vol. 1, 306; emphasis added.

37. Virginia Gazette, January 25, 1783; Costa, Geography of Slavery.

38. Readex, America's Historical Newspapers.

39. Charles Chesnutt, "The Passing of Grandison," in Charles W. Chesnutt: Selected Writings, ed. Sally Ann Ferguson (1899; Boston: Houghton, 2001), 268-82. For more on this story's manipulation of the codes of race, see Martha J. Cutter, "Passing as Narrative and Textual Strategy in Charles Chesnutt's 'The Passing of Grandison," in Passing in the Works of Charles W. Chesnutt, ed. Susan Prothro Wright and Ernestine Pickens Glass (Jackson: University Press of Mississippi, 2010): 39-50. Grandison does not pass for white, however.

40. Brooke Kroeger, Passing: When People Can't Be Who They Are (New York: Public Affairs, 2003), 7-8.

41. Randall Kennedy, Interracial Intimacies: Sex, Marriage, Identity, and Adoption (New York: Vintage, 2004), 285.

42. See Lydia Maria Child, “The Quadroons," Liberty Bell (Boston: Anti-Slavery Fair, 1842): 115-41, Glynis Carr, ed., Online Archive of Nineteenth-Century U.S. Women's Writings, http:// www.facstaff.bucknell.edu/gcarr/19cUSWW/; Hannah Crafts [Hannah Bond], The Bondwoman's Narrative, ed. Henry Louis Gates, Jr. (New York: Warner, 2002); William Wells Brown, Clotel; Or, the President's Daughter (London: Partridge and Oakey, 1853), Documenting the American South, http://docsouth.unc.edu/; and Frances Harper, Iola Leroy: Or Shadows Uplifted (1892; New York: Oxford University Press, 1990). Such a phenomenon of ignorance about possible passing due to being kept in the dark about racial ancestry is also apparent in recent memoirs such as Gregory Williams's Life on the Color Line: The True Story of a White Boy Who Discovered He Was Black (New York: Plume, 1995) and Bliss Boyard's One Drop: My Father's Hidden Life-A Story of Race and Family Secrets (New York: Back Bay, 2008).

43. Erving Goffman, Stigma: Notes on the Management of Spoiled Identity (New York: Aronson, 1974), 79 .

44. Windley, Runaway Slave Advertisements, vol. 2, 271.

45. Ibid., vol. $3,28$.

46. Readex, America's Historical Newspapers.

47. Ibid.

48. Ibid.

49. Windley, Runaway Slaves Advertisements, vol. 2, 338.

50. Sollors, Neither Black nor White yet Both, 142-61.

51. Readex, America's Historical Newspapers.

52. Ibid.

53. Ibid.; emphasis in original text.

54. Naomi Van Tol, Runaway Slave Blog, Memphis and Shelby County Public Library, http:// www.spiny.com/runaway/; emphasis added.

55. Hodges and Brown, "Pretends to Be Free," 21-22; emphasis added.

56. Windley, Runaway Slave Advertisements, vol. 1, 320; emphasis added.

57. Readex, America's Historical Newspapers; emphasis added.

58. Columbus Inquirer, February 9, 1833. See William G. Proctor, "Slavery in Southwest Georgia," Georgia Historical Quarterly 49, no. 1 (1965): 6.

59. The Royal Gazette [New York], no. 675, March 15, 1783; emphasis added. From Hodges and Brown, "Pretends to Be Free," 282.

60. Windley, Runaway Slave Advertisements, vol. 1, 396-97; emphasis added.

61. Ibid., vol. 2, 161; emphasis added.

62. Readex, America's Historical Newspapers; emphasis added.

63. Ibid.; emphasis added.

64. Marshall, “"They Will Endeavor to Pass for Free,"” 168, 173.

65. See James Oliver Horton, "Weevils in the Wheat: Free Blacks and the Constitution, 1787-1860," This Constitution 8 (fall 1985): 4-11 and Gross, What Blood Won't Tell, 48-72.

66. The very light-skinned Ellen Craft cut her hair, wore fashionable male clothing, and passed for a rich Southern gentleman. See William Craft, Running a Thousand Miles for Freedom; or, the Escape of William and Ellen Craft from Slavery (1860; Baton Rouge: Louisiana State University Press, 1986).

67. Richard Hildreth, The Slave; or, Memoirs of Archy Moore, 2 vols. (Boston: Eastburn, 1836), vol. 2, 136.

68. Dred Scott v. Sandford, 60 (19 How.) U.S. 393 (1856), Justia: US Supreme Court, https:// supreme.justia.com/cases/federal/us/60/393/. 
69. Ariela Gross, "Litigating Whiteness: Trials of Racial Determination in the NineteenthCentury South," Yale Law Journal 108, no. 1 (1998): 129.

70. Haney López, "The Social Construction of Race," 4-5; emphasis added.

71. Ibid., 2.

72. Windley, Runaway Slave Advertisements, vol. 2, 51; emphasis added.

73. For another advertisement in which an individual passes for Native American, see the Maryland Gazette from May 21, 1752, which describes a "tall thin Mulatto slave" who ran away from his owner; he "looks very much like an Indian, and will endeavor to pass for such when it suits him." Ibid., vol. 2, 16.

74. Readex, America's Historical Newspapers; emphasis added.

75. See also Smith and Wojtowiz, Blacks Who Stole Themselves: "Run away in July last, from Nicholas Everson ... a mulatto Negroe ... his said master has been informed that he intends to cut his watch coat, to get Indian stockings, and to cut off his hair, and get a blanket, to pass for an Indian" (34).

76. Costa, Geography of Slavery.

77. Statutes against mixed marriages were not formally outlawed in the United States until Loving $v$. State of Virginia (1969).

78. Windley, Runaway Slave Advertisements, vol. 1, 325; emphasis added.

79. Ibid., vol. 2, 245; emphasis added. Free," 173

80. Columbia Telescope, August 8, 1826; see Marshall, “"They Will Endeavor to Pass for

81. Readex, America's Historical Newspapers.

82. Ibid.; emphasis added.

83. Gwenda Morgan and Peter Rushton, "Visible Bodies: Power, Subordination and Identity in the Eighteenth-Century Atlantic World," Journal of Social History 39, no. 1 (2005): 40, 55.

84. See, for example, Brooke Kroeger's misleadingly titled study Passing: When People Can't Be Who They Are (2003) or Clyde Pulley's Blacks Who Pass for Indian and White (Chicago: Adams, 1978). The idea that the passer "denies" his or her (one) "true" race has once again been reinvented in a different time period, for different purposes.

85. Wendy Doniger, The Woman Who Pretended to Be Who She Was: Myths of Self-Imitation (Oxford: Oxford University Press, 2005).

86. Waldstreicher, "Reading the Runaways," 248.

87. Billy G. Smith, "Runaway Slaves in the Mid-Atlantic Region during the Revolutionary Era," in The Transforming Hand of Revolution: Reconsidering the American Revolution as a Social Movement, ed. Ronald Hoffman and Peter J. Albert (Charlottesville: University of Virginia Press, 1995), 199-230. See also John Hope Franklin and Loren Schweninger, Runaway Slaves: Rebels on the Plantation (New York: Oxford University Press, 1999). 